Dept of Pharmacology,

Animal Health Research Institute, Tanta provincial lab.

\title{
PHARMACOKINETIC AND THERAPEUTIC STUDIES ON DANOFLOXACIN AND MARBOFLOXACIN IN LACTATING COWS
}

(With 2 Tables and 2 Figures)

\begin{abstract}
By
W.M.A. EL-SHEIKH and H.M. SHAHEEN*

*Dept of Pharmacology, Faculty of Vet. Med., South Valley University, Qena.

(Received at 11/6/2007)

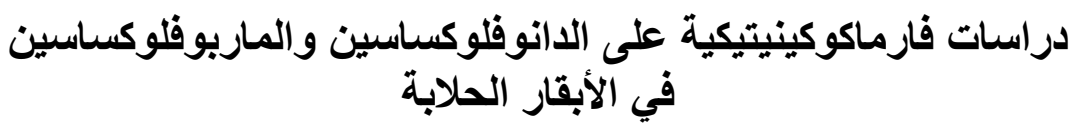

\section{وجيه مصطفي عبل السلام الشبيخ ، حازم محد شاهين}

تم حقن جر عة واحدة من عقاري الدانوفلوكساسين أو الماربوفلوكساسين بالعضل في عدد .

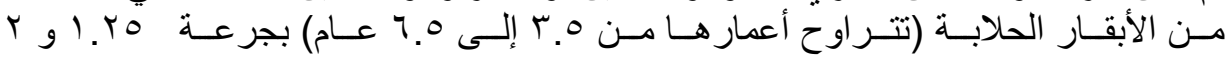
مليجر ام/كجم على التوالي وتم جمع عينات من مصل الام و اللبن وقياس مستوى الدو اعين الدين بهما.

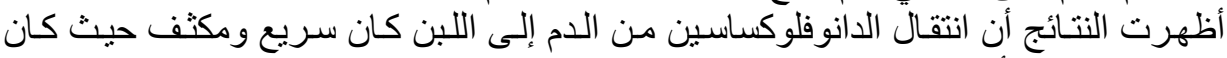

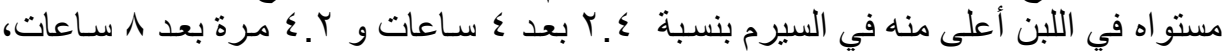

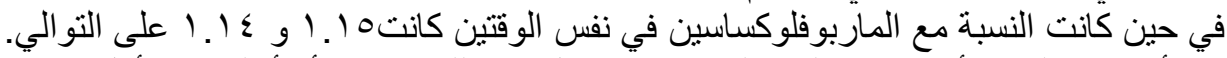

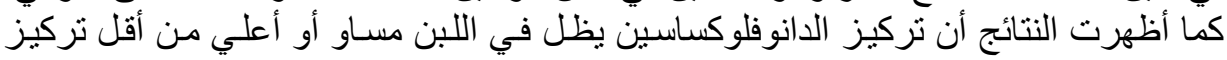

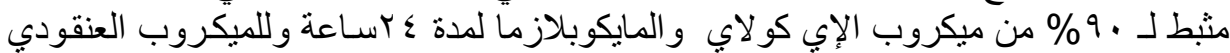

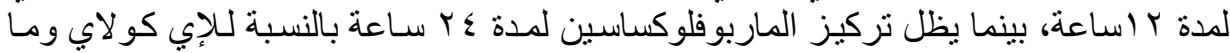

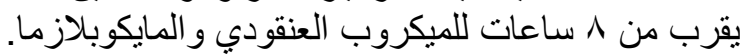

\section{SUMMARY}

A single dose of danofloxacin $(1.25 \mathrm{mg} / \mathrm{kg}$ b.w.) or marbofloxacin $(2 \mathrm{mg} / \mathrm{kg} \mathrm{b.w.)}$ were injected intramuscularly to ten dairy cows between 3.5 and 6.5 years old and weighed 500 to $580 \mathrm{~kg}$. for evaluation its plasma and milk concentrations as well as its antibacterial characteristics against comman mastitis pathogens. Blood and milk samples were collected for determination of concentrations of two drugs by HPLC method. Results showed that, the passage of two drugs from blood into milk were rapid and extensive specially danofloxacin which at 4 and 8 hrs. its milk concentration was 2.4 and 4.2 times higher than the plasma concentration, but this ratios with marbofloxacin was 1.15 and 1.14 at the same time respectively. Danofloxacin concentrations were 
maintained in the cow's milk equal to or higher than the $\mathrm{MIC}_{90}$ of E.coli $(0.06 \mu \mathrm{g} / \mathrm{ml})$ and Mycoplasma spp. $(0.008-0.5 \mu \mathrm{g} / \mathrm{ml})$ for $24 \mathrm{hrs}$. and of S. aureus $(0.18 \mu \mathrm{g} / \mathrm{ml})$ for $12 \mathrm{hrs}$. The marbofloxacin concentrations were still equal to or higher than $\mathrm{MIC}_{90}$ of E.coli $(0.016 \mu \mathrm{g} / \mathrm{ml})$ for $24 \mathrm{hrs}$. and of $S$. aureus $(0.229 \mu \mathrm{g} / \mathrm{ml})$ and Mycoplasma spp. $(0.48 \mu \mathrm{g} / \mathrm{ml})$ for nearly $8 \mathrm{hrs}$.

Key words: Pharmacokinetic, danofloxacin, marbofloxacin, cows

\section{INTRODUCTION}

Fluoroquinolones are one of the most useful classes of antimicrobial agents used today in human and animal medicine because of their spectrum and their physico-chemical properties. As such, their popularity is increasing in clinical situations (Wolfson and Hooper, 1989, and Sárközy, 2001). The antimicrobial activity spectrum of fluoroquinolones (specially third generation as danofloxacin and marbofloxacin) is wide and includes most Gram-negative and some Gram-positive bacteria, mycoplasmas and intracellular pathogens such as Brucella and chlamydia species; but has poor activity against anaerobes (Hannan et al., 1989; Wolfson and Hooper, 1989; Neu, 1991; and Appelbaum and Hunter, 2000).

This fluoroquinolones acts directly on the bacterial DNA by penetrating the bacterium by simple diffusion and the target is a bacterial enzyme DNA gyrase (Bousquet-Melou et al. (2002). Particularly, the third generation quionlone has a flat structure that allows its insertion between the chains of the DNA molecule and acts as concentrationdependent antibiotics for Gram-negative bacteria, whereas their action against certain Gram-positive bacteria is generally considered timedependent (Hooper and Wolfson, 1993 and Bousquet-Melou et al., 2002).

As the pharmacokinetic parameters of antibiotics may change in lactating animals (Oukessou et al., 1990; Petracca et al., 1993 and Soback et al., 1994) and the plasma-to-milk drug concentration ratio of these drugs is often unknown (Atkinson and Begg, 1990). So, the aim of the present study was determination of the pharmacokinetic parameters $\left(\mathrm{C}_{\max }\right.$, maximum serum concentration; $\mathrm{t}_{\mathrm{max}}$, time of maximum concentration; $\mathrm{t}_{1 / 2 \mathrm{el}}$, elimination half-life time and AUC, area under curve) and penetration of danofloxacin and marbofloxacin from blood into milk in lactating cows following their intramuscular injections in 
recommended dose was calculated and expressed as $\mathrm{C}_{\text {max-milk }} / \mathrm{C}_{\text {max-serum }}$, $\mathrm{AUC}_{\text {milk }} / \mathrm{AUC}_{\text {serum }}$, and $\mathrm{t}_{1 / 2 \mathrm{el} \text {-milk }} / \mathrm{t}_{1 / 2 \mathrm{el} \text {-serum. }}$.

\section{MATERIALS and METHODS}

\section{A-Drugs:-}

1- Danofloxacin: - $\left(\right.$ Advocin $^{\circledR} 2.5 \%$ injectable solution, Pfizer Ltd). It is a synthetic fluoroquinolone $3^{\text {rd }}$ generation with broad spectrum antibacterial activity. It is used in treatment of respiratory diseases in chickens, cattle and pigs (Schneider et al., 1993) and has a potential use in the treatment of bovine mastitis (Shem-Tov et al., 1998).

2- Marbofloxacin: - (Marbocyl ${ }^{\circledR} 10 \%$ injectable solution, Vétoquinol). It is a synthetic fluoroquinolone $3^{\text {rd }}$ generation devoloped by Vétoquinol exclusivley for veterinary use for oral and parenteral administrations to cattle; including lactating dairy cattle, and pigs for treatment of mastitis and respiratory diseases. It has a good therapeutic antibacterial activity for cattle, pigs, dogs, cats and other species (Hooper and Wolfson, 1993; Thomas et al., 1998 and Thoulon et al., 1999)

\section{B- Animals:-}

Ten Friesian cows between 3.5 and 6.5 years old and weighed 500 to $580 \mathrm{~kg}$., fed antibiotic free ration, not received any drug for at least one month, produced 15-24 liters of milk/day, their udders secreted macroscopically normal milk of $\mathrm{pH}$ 6.6-6.9, with somatic cell count of $<500000 / \mathrm{ml}$, were injected intramuscularly once; just after the morning milking, with danofloxacin $(\mathrm{n}=5)$ at a dose of $1.25 \mathrm{mg} / \mathrm{kg} \mathrm{b.w}$. or marbofloxacin $(\mathrm{n}=5)$ at a dose of $2 \mathrm{mg} / \mathrm{kg} \mathrm{b} . \mathrm{w}$.

\section{C- Sampling:-}

Blood and milk samples ( $5 \mathrm{ml}$ of each) were collected prior and at $1 / 2,1,2,4,8,12,24.30,36 \mathrm{hrs}$. after drugs injection. Collected samples (serum and milk) were stored at $-20^{\circ} \mathrm{c}$ until estimation of drug concentrations (Shojaee-Aliabadi and Lees, 2003). Danofloxacin and marbofloxacin concentrations were mesured by HPLC with UV detector with quantitation limits of $0.05 \mu \mathrm{g} / \mathrm{ml}$ for danofloxacin and $0.01 \mu \mathrm{g} / \mathrm{ml}$ for marbofloxacin according methods described by McKellar et al. (1999), and Schneider et al. (2004).

\section{D- Analysis:-}

Statistical were carried out using " $\mathrm{t}$ " test according to SAS (1987), and the kinetic parameters $\left(\mathrm{C}_{\max }, \mathrm{t}_{\max }, \mathrm{t}_{1 / 2 \mathrm{el}}\right.$, and AUC) were calculated according to Baggot (1977) and penetration of danofloxacin and marbofloxacin from blood into milk in lactating cows following 
their intramuscular injections in recommended dose was calculated and expressed as $\mathrm{C}_{\text {max-milk }} / \mathrm{C}_{\text {max-serum, }}, \mathrm{AUC}_{\text {milk }} / \mathrm{AUC}_{\text {serum }}$, and $\mathrm{t}_{1 / 2 \mathrm{el}-\text { milk }} / \mathrm{t}_{1 / 2 \mathrm{el}}$ serum according to Shem-Tov et al. (1998).

\section{RESULTES}

Danofloxacin and marbofloxacin concentrations in serum and milk shown that the two drugs were passed rapidly from blood into milk in injected cows (Table 1 and Fig. 1-2), reach maximal concentration in milk after two hours after injection, danofloxacin levels in serum and milk were $0.35 \pm 0.144$ and $0.70 \pm 0.292 \mu \mathrm{g} / \mathrm{ml}$ and marbofloxacin levels were $1.07 \pm 0.033$ and $1.31 \pm 0.029 \mu \mathrm{g} / \mathrm{ml}$ respectively. On the other hand, at $24 \mathrm{hrs}$. danofloxacin cannot detect in serum but still in milk until 30 hrs. while marbofloxacin was detected after $24 \mathrm{hrs}$. in serum and milk with levels $0.03 \pm 0.017$ and $0.025 \pm 0.003 \mu \mathrm{g} / \mathrm{ml}$ respectively.

Table (2) showed that, $\mathrm{T}_{\max }$ of danofloxacin and marbofloxacin in serum were $1 \pm 0.05$ and $1 \pm 0.01$ hour respectively while in milk was variable $(8 \pm 0.11 \mathrm{hrs}$. for danofloxacin and $2 \pm 0.06 \mathrm{hrs}$. for marbofloxacin).

Table 1: Serum and milk concentrations after single i.m injection of danofloxacin (1.25 mg/kg b.w.) or marbofloxacin $(2 \mathrm{mg} / \mathrm{kg}$ b.w.) in lactating cows $(\mu \mathrm{g} / \mathrm{ml})$.

\begin{tabular}{|c|c|c|c|c|}
\hline \multirow[b]{2}{*}{$\begin{array}{c}\text { Time of } \\
\text { sampling }\end{array}$} & \multicolumn{2}{|c|}{ Danofloxacin } & \multicolumn{2}{|c|}{ Marbofloxacin } \\
\hline & $\begin{array}{c}\text { Serum } \\
(\mathrm{n}=5) \\
\text { mean } \pm \text { S.E. }\end{array}$ & $\begin{array}{c}\text { Milk } \\
(\mathrm{n}=5) \\
\text { mean } \pm \text { S.E }\end{array}$ & $\begin{array}{c}\text { Serum } \\
(\mathrm{n}=5) \\
\text { mean } \pm \text { S.E }\end{array}$ & $\begin{array}{c}\text { Milk } \\
(\mathrm{n}=5) \\
\text { mean } \pm \text { S.E }\end{array}$ \\
\hline Pre-injection & 0.00 & 0.00 & 0.00 & 0.00 \\
\hline $1 / 2 \mathrm{~h}$ & $0.33 \pm 0.027$ & $0.09 \pm 0.029^{+}$ & $0.77 \pm 0.029 *$ & $0.055 \pm 0.003$ \\
\hline $1 \mathrm{~h}$ & $0.35 \pm 0.144$ & $0.31 \pm 0.027$ & $1.42 \pm 0.029 *$ & $0.72 \pm 0.033^{+}$ \\
\hline $2 \mathrm{~h}$ & $0.35 \pm 0.041$ & $0.70 \pm 0.292$ & $1.07 \pm 0.033 *$ & $1.31 \pm 0.029^{+}$ \\
\hline $4 \mathrm{~h}$ & $0.34 \pm 0.034$ & $0.80 \pm 0.332$ & $0.75 \pm 0.025^{*}$ & $0.86 \pm 0.027$ \\
\hline $8 \mathrm{~h}$ & $0.19 \pm 0.029$ & $0.79 \pm 0.029^{+}$ & $0.37 \pm 0.035^{*}$ & $0.42 \pm 0.049$ \\
\hline $12 \mathrm{~h}$ & $0.055 \pm 0.003$ & $0.12 \pm 0.027$ & $0.12 \pm 0.041 *$ & $0.18 \pm 0.035$ \\
\hline $24 \mathrm{~h}$ & ND & $0.052 \pm 0.002^{+}$ & $0.03 \pm 0.017 *$ & $0.025 \pm 0.003$ \\
\hline $30 \mathrm{~h}$ & ND & $0.052 \pm 0.002^{+}$ & ND & ND \\
\hline $36 \mathrm{~h}$ & ND & ND & ND & ND \\
\hline
\end{tabular}

ND=Not Detected.

$*$ And $+=$ significant at $(\mathrm{p}<0.05)$. 
Table 2: Pharmacokinetic parameters in serum and milk after single i.m. injection of danofloxacin $(1.25 \mathrm{mg} / \mathrm{kg} \quad$ b.w.) or marbofloxacin $(2 \mathrm{mg} / \mathrm{kg}$ b.w.) in lactating cows.

\begin{tabular}{|c|c|c|c|c|}
\hline \multirow[b]{2}{*}{$\begin{array}{l}\text { pharmacokinetic } \\
\text { parameters }\end{array}$} & \multicolumn{2}{|c|}{ Danofloxacin } & \multicolumn{2}{|c|}{ Marbofloxacin } \\
\hline & $\begin{array}{c}\text { Serum } \\
(\mathrm{n}=5) \\
\text { mean } \pm \text { S.E }\end{array}$ & $\begin{array}{c}\text { Milk } \\
(\mathrm{n}=5) \\
\text { mean } \pm \text { S.E }\end{array}$ & $\begin{array}{c}\text { Serum } \\
(\mathrm{n}=5) \\
\text { mean } \pm \text { S.E }\end{array}$ & $\begin{array}{c}\text { Milk } \\
(\mathrm{n}=5) \\
\text { mean } \pm \text { S.E }\end{array}$ \\
\hline $\mathrm{C}_{\max } \quad \mu \mathrm{g} / \mathrm{ml}$ & $0.369 \pm 0.02$ & $0.80 \pm 0.06$ & $1.41 \pm 0.03 *$ & $1.31 \pm 0.04^{+}$ \\
\hline $\begin{array}{ll}\max & h\end{array}$ & $1 \pm 0.05$ & $8 \pm 0.11^{+}$ & $1 \pm 0.01$ & $2 \pm 0.06$ \\
\hline $\mathrm{t}_{1 / 2 \mathrm{el}} \quad \mathrm{h}$ & $3 \pm 0.11$ & $4.2 \pm 0.23$ & $3 \pm 0.12$ & $4 \pm 0.12$ \\
\hline AUC $\quad \mu g / m l . h$ & $3.20 \pm 0.14$ & $11.06 \pm 0.45^{+}$ & $7.42 \pm 0.22 *$ & $5.95 \pm 0.02$ \\
\hline $\mathrm{C}_{\text {max-milk }} / \mathrm{C}_{\max \text {-serum }}$ & \multicolumn{2}{|c|}{2.17} & \multicolumn{2}{|c|}{0.93} \\
\hline $\mathrm{t}_{1 / 2 \mathrm{el} \text {-milk }} / \mathrm{t}_{1 / 2 \mathrm{el} \text {-serum }}$ & \multicolumn{2}{|c|}{1.4} & \multicolumn{2}{|c|}{1.33} \\
\hline $\mathrm{AUC}_{\text {milk }} / \mathrm{AUC}_{\text {serum }}$ & \multicolumn{2}{|c|}{3.46} & \multicolumn{2}{|c|}{0.80} \\
\hline
\end{tabular}

$*$ And $+=$ significant at $(\mathrm{p}<0.05)$.

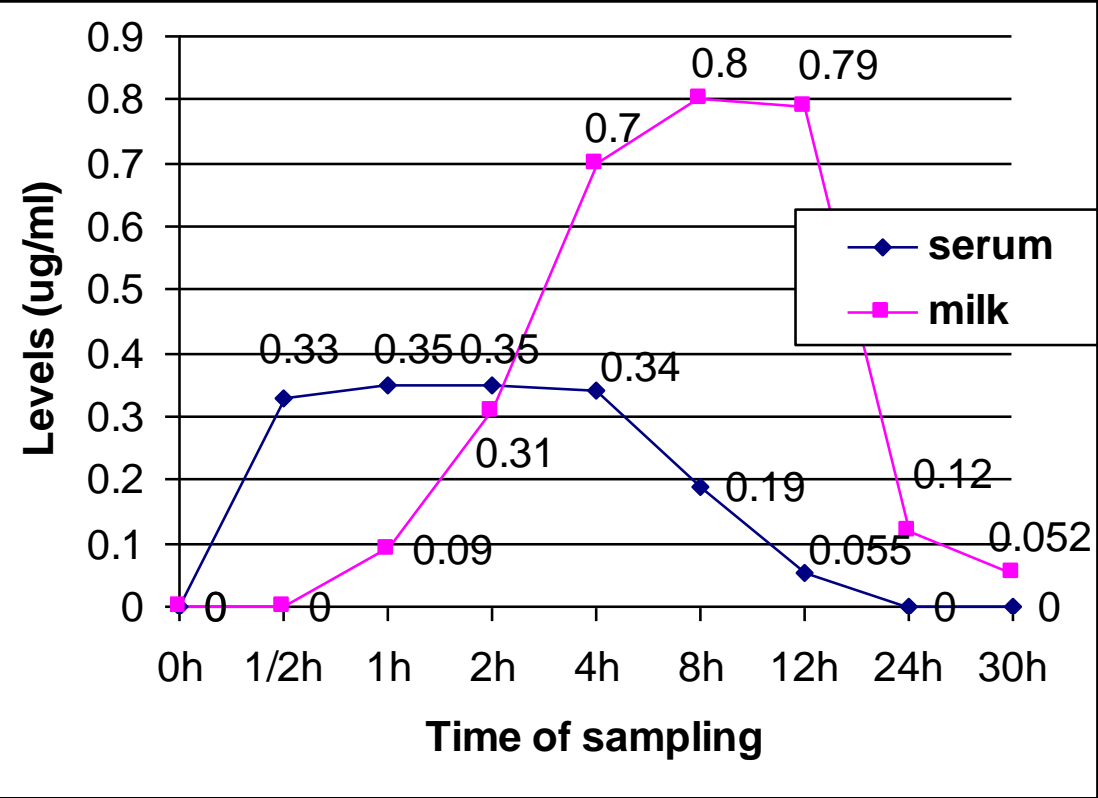

Fig. 1: Serum and milk concentrations after single i.m injection of danofloxacin (1.25 mg/kg b.w.) in lactating cows ( $\mu \mathrm{g} / \mathrm{ml})$. 


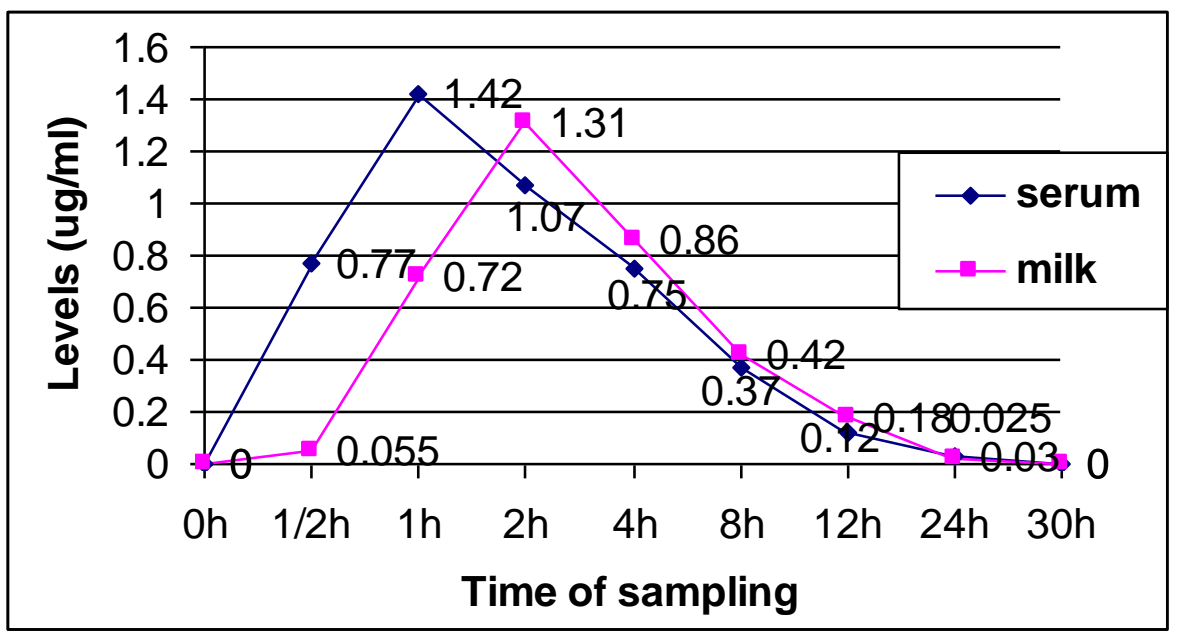

Fig. 2: Serum and milk concentrations after single i.m injection of marbofloxacin ( $2 \mathrm{mg} / \mathrm{kg}$ b.w.) in lactating cows $(\mu \mathrm{g} / \mathrm{ml})$.

\section{DISCUSSION}

It is generally accepted that xenobiotics cross the blood-milk barrier in the udder by non ionic passive-diffusion and the extent of diffusion is greatly influenced by the physicochemical properties of the drug (Rasmussen, 1966 and Atkinson and begg, 1990) and due to presence of a carboxylic acid and basic amine-functional groups in danofloxacin and marbofloxacin, they are amphotric and considered zwitterionic and so between pH. 6 and 8, these drugs are sufficiently lipid-soluble to be able to penetrate tissues resulting extensive penetration from blood into the cow's milk (Brown, 1996) which therefore predictable on the basis of the "ion trap" mechanism (Rasmussen, 1966 and Atkinson and begg, 1990).

In the present study the pharmacokinetic interpretation of danofloxacin and marbofloxacin concentrations data; in serum and milk, reveals the rapid and extensive penetration of the two drugs from blood into milk. This is similar to results obtained by Soback et al., (1994); Brown, (1996); Shem-Tov et al., (1997) and Schneider et al., (2004) where they recorded the very large distribution of these two drugs in the body of lactating cows.

The first important finding in the present study was the shift between plasma and milk kinetic profiles that appeared after $2 \mathrm{hrs}$. specially with danofloxacin which at 4 and $8 \mathrm{hrs}$. its milk concentration 
was 2.4 and 4.2 times higher than the plasma concentration, but with marbofloxacin this shift occurs by relatively little degree (was 1.15 and 1.14 at the same time) respectively. In details, $\mathrm{C}_{\max }$ for danofloxacin in serum and milk were $0.369 \pm 0.02$ and $0.80 \pm 0.06 \mu \mathrm{g} / \mathrm{ml}$ after 1 and $8 \mathrm{hrs}$. and for marbofloxacin were $1.41 \pm 0.03$ and $1.31 \pm 0.04 \mu \mathrm{g} / \mathrm{ml}$ after 1 and 2 hrs. respectively, and whereas danofloxacin at $24 \mathrm{hrs}$. not detected in serum, its mean concentrations $(0.052 \pm 0.002 \mu \mathrm{g} / \mathrm{ml})$ in milk still until $30 \mathrm{hrs}$., in contrast marbofloxacin concentrations were measured in two fluids until $24 \mathrm{hrs}$. with nearly similar values $(0.03 \pm$ 0.017 in serum and $0.025 \pm 0.003 \mu \mathrm{g} / \mathrm{ml}$ in milk). Nearly similar results were previously reported by Shem-Tov et al., (1998) with danofloxacin in lactating cows, where they found that danofloxacin concentration in milk at 2 hrs. was equal to those in serum and at 4 and $6 \mathrm{hrs}$. were 2.2 and 5.5 times greater than the corresponding concentrations in serum. But they not detect the drug in serum and milk after 12 and $24 \mathrm{hrs}$. respectively. For marbofloxacin, Schneider et al., (2004) mentioned that $\mathrm{C}_{\max }$ in serum was $1.667 \mu \mathrm{g} / \mathrm{ml}$ after $45 \mathrm{~min}$ and in milk was $1.024 \mu \mathrm{g} / \mathrm{ml}$ after $2.5 \mathrm{hrs}$., and $\mathrm{C}_{23 \mathrm{~h}}$ in serum was 0.017 and in milk was $0.013 \mu \mathrm{g} / \mathrm{ml}$. In keeping with this lines (VMRI, 2006) recored $\mathrm{C}_{\max }$ for marbofloxacin in serum $1.5 \mu \mathrm{g} / \mathrm{ml}$ after less than $1 \mathrm{hr}$. and in milk $1.02 \mu \mathrm{g} / \mathrm{ml}$ after 2.5 hrs.

Comparative studies strongly suggest that the lactations may increase the rate of elimination of some fluoroquinolones from the serum, where the mean elimination half-life $\left(t_{1 / 2 \mathrm{el}}\right)$ in serum may be shorter in lactating than non-lactating animals of the same species. The intravenous $t_{1 / 2 \beta}$ of enrofloxacin in non lactating cattle was $5.5 \pm 0.9 \mathrm{hrs}$. (Sheer, 1987) whereas the corresponding value in lactating cows was $1.7 \mathrm{hr}$.(Walser et al., 1993) and $1.68 \pm 0.18 \mathrm{hr}$. in another study (Kaartinen et al., 1996). For marbofloxacin, it was $5.72 \pm 1.17 \mathrm{hrs}$. in non lactating adult cattle (Thomas et al., 1994) and was $2.07 \pm 0.66 \mathrm{hrs}$. in lactating cows (Shem-Tov et al., 1997). In the present study, the $t_{1 / 2 \mathrm{el}}$ in serum was $3 \pm 0.11$ and $3 \pm 0.12 \mathrm{hrs}$. for danofloxacin and marbofloxacin respectively, which relatively shorter than $3.5-4.5 \mathrm{hrs}$. which reported by (Grimshaw et al., 1990 and Giles et al., 1991) following administration of danofloxacin (i.v., i.m. and s.c.) to non lactating cattle. A shorter than (4-7 hrs.) that reported for marbofloxacin in non lactating cows (VMRI, 2006).

In the present study, the ratios $\mathrm{C}_{\text {max-milk }} / \mathrm{C}_{\text {max-serum }}$ was 2.17 and $0.93, \mathrm{t}_{1 / 2 \text { el-milk }} / \mathrm{t}_{1 / 2 \mathrm{el} \text {-serum_was }} 1.4$ and 1.33 and $\mathrm{AUC}_{\text {milk }} / \mathrm{AUC}_{\text {serum }}$ was 3.46 and 0.80 for danofloxacin and marbofloxacin respectively which 
supported with earlier findings on danofloxacin by Shem-Tov et al. (1998) and on marbofloxacin by Schneider et al. (2004) their ratios were 2.54 and $0.61,1.26$ and 1.23 and 3.52 and 0.83 for danofloxacin and marbofloxacin respectively. These results indicating greater persistence of drug concentrations in the milk relative to those in serum, with superiority for danofloxacin in reaching to milk and persisting for a longer time, but for fairness if danofloxacin has this good specialty we found that marbofloxacin has another good properties of short withdrawal period in milk that give it superiority when used in treating diseases other than mastitis.

The previously reported minimal inhibitory concentrations (MIC) of danofloxacin for $90 \%$ of the field isolates of E.coli $0.06 \mu \mathrm{g} / \mathrm{ml}$ (Toutain, 2003), for $S$. aureus was $0.18 \mu \mathrm{g} / \mathrm{ml}$ (Cruz et al., 1998) and for Mycoplasma sp. was $0.008-0.5 \mu \mathrm{g} / \mathrm{ml}$ (Cooper et al., 1993), and that record for marbofloxacin with E.coli was $0.016 \mu \mathrm{g} / \mathrm{ml}$, S. aureus was $0.229 \mu \mathrm{g} / \mathrm{ml}$ (Schneider et al., 2004) and for Mycoplasma sp. was $0.48 \mu \mathrm{g} / \mathrm{ml}$ (Drugeon et al., 1997). Depending on these results the present study showed that, danfloxacin concentrations were maintained in the cow's milk equal to or higher than the $\mathrm{MIC}_{90}$ for E.coli and Mycoplasma sp. for $24 \mathrm{hrs}$. and higher than the $\mathrm{MIC}_{90}$ for $S$. aureus for 12 hrs.. These results were agreemented to that mentioned by Shem-Tov et al. (1998). Marbofloxacin concentrations were maintained equal to or higher than $\mathrm{MIC}_{90}$ of E.coli for $24 \mathrm{hrs}$. and for $S$. aureus and Mycoplasma spp.. for nearly $8 \mathrm{hrs}$., and although of this result its effect alone as parenteral injection for mastitis treatment is still controversial due to steep marbofloxacin milk profile which is nearly parallel to the plasma profile and most trials for its use in mastitis treatment usually were accompanied with local treatment. As Thomas et al. (1998) which mentioned that marbofloxacin parenterally was effective on mastitis due to coibacilli when combined with intramammary treament which only has an effect on Gram-positive mastitis (cloxacillin), also Grandemange and Davot, (2002) found; in a field trial, that parenteral injection of marbofloxacin in combination with a local cloxacillin treatment showed efficacy in treatment of acute clinical coliform mastitis in dairy cows, and in another trial for the same authors found that marbofloxacin parenterally showed some expected efficacy against $S$. aureus-induced infections, especially when associated with a local ß-lactamine treatment. On the contrast we found Schneider et al. (2004) told that, a possible efficacy for marbofloxacin against E. coli-induced mastitis is 
expected after its repeated intramuscular administrations at a daily dose rate of $2 \mathrm{mg} / \mathrm{kg}$.

The main pharmacokinetic/pharmacodynamic

(PK/PD) parameters correlating with efficacy, minimising the risk of development of resistance and the best surrgate of drug activity are the $\mathrm{C}_{\max }$ /MIC and AUC/MIC ratios (Toutain et al., 2002) specially if its endpoints are equal to or thigher than 10 and 125 hrs. respectively (Hyatt et al., 1995; Schentag, 1999; Pickerill et al., 2000 and Schentag et al., 2001). In this study for danofloxacin $\mathrm{C}_{\text {max-milk }} / \mathrm{MIC}$ and $\mathrm{AUC}_{\text {milk }} / \mathrm{MIC}$ for $E$. coli was 13.33 and $184.33 \mathrm{hrs}$., for $S$. aureus was 4.4 and $61.44 \mathrm{hrs}$. and for Mycoplasma spp.. was 1.6 and 22.12 hrs. whereas for marbofloxacin this ratios were 81.88 and 371.88 hrs. for E. coli, 5.72 and $25.98 \mathrm{hrs}$. for S. aureus and 2.73 and $12.4 \mathrm{hrs}$. for Mycoplasma spp.. respectively. Although, these endpoints are only reached for E. coli strains and relatively far away for $S$. aureus and Mycoplasma spp..for the two drugs, some activity against $S$. aureus and Mycoplasma spp.. may be expected because the activity of fluoroquinolones against Gram-positive strains is rather time dependent (Schneider et al., 2004).

Depeding on results of this study specially a high peak milk concentration that maintained as MIC over the assuming dosage interval (either 12 or $24 \mathrm{hrs}$.) for the two drugs and with recalling that fluoroquinolones are concentration dependent antimicrobial agents (Hooper and Wolfson, 1993 and Bousquet-Melou et al., 2002) the potential use of danofloxacin and marbofloxacin in the treatment of bovine mastitis can be suggested. With taking in account that danofloxacin is justified at dose of $1.25 \mathrm{mg} / \mathrm{kg} \mathrm{q} 24 \mathrm{hrs}$. for treatment of bovine mastitis associated with Gram-negative pathogens and $1.25 \mathrm{mg} / \mathrm{kg} \mathrm{q} 12 \mathrm{hrs}$. for treatment of that caused by $S$. aureus. or Mycoplasma spp.., but the uses of marbofloxacin alone as mastitis treatment is still controversial and need futher field trials .

\section{ACKNOWLEDGMENTS}

We thank Prof. Dr. Magdy Ibrahim Abd El-Aziz (Professor of Vet. Pharmacology, Chairman of Pharmacology and Forensic Medicine \& Toxicology Department, Kafr El-Sheikh University) for his sincere help in kinetic measurements. 


\section{REFERANCES}

Appelaum, P.C. and Hunter, P.A. (2000): The fluoroquinolone antibacterials: past, present and future Int. Antimicrob. Agents, (16): 5-15.

Atkinson, H. and Begg, E. (1990): Prediction of drug distribution into human milk from physicochemical characteristics. Clinical Pharmacokinetics, (18): 151-167.

Baggot, J.D. (1977): Principles of Drug Deposition in Domestic Animals: The Basis of Veterinary Clinical Pharmacology. WB Saunders, Philadelphia 144-189.

Bousquet-Melou, A.; Bernard, S.; Schneider, M. and Toutain P.L. (2002): Pharmacokinetics of marbofloxacin in horses. Equine Vet. J. 34 (4): 366-372.

Brown, S.A. (1996): Fluoroquinolones in animal health. J. Vet. Pharmacol. Ther. (19): 1-14.

Cooper, A.C.; Fuller, J.R.; Fuller, M.K.; Whittlestone, P. and Wise, D. R. (1993): In vitro activity of danofloxacin, tylosin and oxytetracycline against mycoplasmas of veterinary importance. Res. Vet. Sci. (54): 329-334.

Cruz, A.D.; Batista, G.C. M.; Modolo, J.R.; Gottschalk, A.F. and Lopes, C.A.M. (1998): Antimicrobial activity of danofloxacin and seven other drugs against Staphylococcus aureus from mastitis. Arquivo Brasileiro de Medicina Veterinaria V50 No. 4: 369373.

Drugeon, H.; Thomas, V.; Guillardeau, L. and Thomas, E. (1997): Antibacterial activity of marbofloxacin against bovine respiratory isolates. Proceeding Of the $7^{\text {th }}$ congress of european association for veterinary pharmacology and toxicology (EAVPT) Madrid, 6-10July, 138-139.

Giles, C.J.; Magonigle, R.A.; Grimshaw, W.T.R.; Tanner, A.C.; Risk, J. E.; Lynch, M.J. and Rice, J.R. (1991): Clinical pharmacokinetics of parenterally administered danofloxacin in cattle. J. Vet. Pharmacol. Ther. (14): 400-410.

Grandemange, E. and Davot, J.L. (2002): Field evaluation of the efficacy of marbofloxacin in the treatment of acute mastitis due to Gram-negative bacteria in the dairy cow. Cattle Practice 10:57-62. 
Grimshaw, W.T.R.; Magonigle, R.A.; Giles, C.J.; Tanner, A.C.; Risk, J.E.; Lynch, M.J. and Rice, J.R. (1990): The pharmacokinetics of danofloxacin in cattle. Proceeding, $16^{\text {th }}$ Worled Congress Salvador Bahia, Brazil.

Hannan, P.C.T.; O'Hanlon, P.J. and Rogers, N.M. (1989): In vitro evalution of various quinolone antibacterial agents against veterinary mycoplasma and porcine respiratory bacterial pathogens. Res. Vet. Sci. (46): 202-211.

Hooper, D.C. and Wolfson, J.S. (1993): Mechanism of quinolones action and bacerial killing. Quinolone Antimicrobi. Agents $2^{\text {nd }}$ Ed. American Siciety for Microbiology, Washington, D.C. 5375.

Hyatt, J.M.; McKinnon, P.S.; Zimmer, G.S. and Schentag, J.J. (1995): The importance of pharmacokinetic/pharmacodynamic surrogate markers to outcome. Clin. Pharmacokinetics (28): 143-160.

Kaartinen, L.; Salonen, M.; Alli, L. and Pyorala, S. (1996): Pharmacokinetics of danofloxacin after single intravenous, intramuscular and subcutaneous injections in lactating cows. J. Vet. Pharmacol. Ther. (18): 357- 362.

McKellar, Q.; Gibson, I.; Monteiro, A. and Bregante, M. (1999): Pharmacokinetics of enrofloxacin and danofloxacin in plasma, inflammatory exudate and bronchial secretions of calves following subcutaneous administraion. Antimicrob. Agents Chemother., 43 (8): 1988-1992.

$\mathrm{Neu}$, H.C. (1991): Synergy and antagonism of combinations with quinolones. Eur. J. Clin. Microbiol. Infect. Dis. (10): 255-261.

Oukessou, M.; Benlamlich, S. and Toutain, P.L. (1990): Benzylpenicillin kinetics in the ewe: influence of pregnancy and lactation. Research in Vet. Sci., (49): 190-193.

Petracca, K.; Riond, J.L.; Graser, T. and Tanner, M. (1993): Pharmacokinetics of the gyrase inhibitor marbofloxacin: influence of pregnancy and lactation in sows. J. Vet. Med., A (40): 73-79.

Pickerill, K.E.; Paladino, J.A. and Schentag, J.J. (2000): Comparison of the fluoroquinolones based on pharmacokinetic and pharmacodynamic parameters. Pharmacotherapy (20): 417-428. 
Rasmussen, F. (1966): Studies on the mammary excretion and absorption of drugs. Carl. Fr. Mortensen Publications, Copenhagen.

Sárközy, G. (2001): Quinolones: a class of antimicrobial agents. Vet. Med-Czech, 46 (9-10): 257-274.

SAS (Statistical Analysis System), (1987): SAS User's Guide: Statistical Methods. SAS Institute, Inc., Cary, North Carolina.

Schentag, J.J. (1999): Antimicrobial action and pharmackinetics/pharmacodynamics: The use of AUIC to improve efficacy and avoid resistance. J. Chemother. (11): 426-439.

Schentag, J.J.; Gilliland, K.K. and Paladino, J.A. (2001): What have we learned from pharmacokinetic and pharmacodynamic theories? Clin. Infect. Dis. 32:S39-S46

Schneider, M.; Vallé, M.; Woehrlé, F. and Boisramé, B. (2004): Pharmacokinetics of marbofloxacin in lactating cows after repeated intramuscular administrations and pharmacodynamics against mastitis isolated strains. J. Dairy Sci. (87): 202-211.

Schneider, R.P.; Ericson, J.F.; Lynch, M.J. and Fonda, H.G. (1993): Confirmation of danofloxacin residues in chicken and cattle liver by microbore- HPLC electrospray lonization tandem mass spectrometry. Biol. Mass. Spec. (22): 595-599.

Sheer, M. (1987): Concentration of active ingredient in the serum and in tissues after oral and parenteral administration of Baytril ${ }^{\circledR}$. Vet. Med. Rev. (2): 104-118.

Shem-Tov, M.; Rav-Hon, O.; Ziv, G.; Lavi, E.; Glickman, A. and Saran, A. (1998): Pharmacokinetics and penetration of danofloxacin from the blood into the milk of cows. J. Vet. Pharmacol. Therap. (21): 209-213.

Shem-Tov, M.; Ziv, G.; Glickman, A. and Saran, A. (1997): Pharmacokinetics and penetration of marbofloxacin from blood into the milk of cows and ewes. J. Vet. Med. (44): 511-519.

Shojaee Aliabadi, F. and Lees, P. (2003): Pharmacokineticpharmacodynamic integration of danofloxacin in the calf. Research in Vet. Sci., (74): 247-259.

Soback, S.; Gips, M.; Bialer, M. and Bor, A. (1994): Effect of lactation on single dose pharmacokinetics of norfloxacin in ewes. Antimicrob. Agents Chemother., (38): 2336-2339. 
Thomas, E.; Grandemange, E.; Davot, J.L. and Raguet, Y. (1998): Efficacité de Marbocyl 10\% dans le traitement des mammites aiguës à bactéries Gram-négatives des vaches laitières: résultats d'un essai terrain. Congrès de la Société Française de Buiatrie. Paris, 25-26 Novambre, poster.

Thomas, V.J.; Deleforge, J. and Boisramé, B. (1994): Pharmacokinetics of marbofloxacin in pre-ruminant and ruminant cattle. In Proc. 6th Congr. Europ. Assoc. Vet. Pharmacol. Toxicol. Blackwell Science Ltd., Edinburgh: 60-61.

Thoulon, F.; Scheider, M.; Woerlé, F. and Boisramé, B. (1999): Use of marbofloxacin in the horse. $6^{\text {th }}$ WEVA Congress. Joumées AVEF, Paris 30 Septembre- 30 Octobre, poster.

Toutain, P.L. (2003): Antibiotics treatment of animals- A different approach to rational dosing. The Vet. J., 165: 98-100.

Toutain, P.L.; Del Castillo, J.R.E. and Bousquet-Melou, A. (2002): The pharmacokinetic-pharmacodynamic approach to a rational dosage regimen for antibiotics. Res. Vet. Sci., (73): 105-114.

Veterinary Medical Research Institute (VMRI), (2006): Summary of product characteristics (Marbocyl 10\%). Copyright ${ }^{\odot}$ 2006, College of Veterinary Medicine, Iowa State University.

Walser, K.; Gandsorfer, B.; Steinberger, A.; Treitinger, W. and Winter, T.H. (1993): Studies on the antibacterial activity and pharmacokinetics of enrofloxacin (Baytril ${ }^{\circledR}$ ) in Lactating cows. Tierärztl. Umschau. (48): 414-419.

Wolfson, J.S. and Hooper, D.C. (1989): Fluoroquinolone antimicrobial agents. Clin. Microbiol. Rev. (2): 378-424. 